\title{
Effect of the supporting zeolite structure on Cr biosorption: Performance of a single-step reactor and of a sequential batch reactor-A comparison study
}

\author{
Hugo Figueiredo $^{\mathrm{a}}$, Bruna Silva ${ }^{\mathrm{a}}$, Cristina Quintelas $^{\mathrm{a}}$, Isabel C. Neves ${ }^{\mathrm{b}, *}$, Teresa Tavares $^{\mathrm{a}, * *}$ \\ a IBB - Instituto de Biotecnologia e Bioengenharia, Centro de Engenharia Biológica, Universidade do Minho, Campus de Gualtar, 4710-057 Braga, Portugal \\ b Departamento de Química, Centro de Química, Universidade do Minho, Campus de Gualtar, 4170-057 Braga, Portugal
}

\section{A R T I C L E I N F O}

\section{Article history:}

Received 29 March 2010

Received in revised form 5 July 2010

Accepted 6 July 2010

\section{Keywords:}

Chromium

Zeolite

Biosorption

Batch reactor

Arthrobacter viscosus

\begin{abstract}
A B S T R A C T
This work presents a study on the applicability of a zeolite-biomass system to the entrapment of metallic ions, starting from $\mathrm{Cr}(\mathrm{VI})$ solutions up to $100 \mathrm{mg}_{\mathrm{Cr}} / \mathrm{L}$, in batch processes. The effect of the zeolitic support on the overall system performance was evaluated comparing two large pore zeolitic structures which differ in chemical composition and ion-exchange capacity: Faujasite (HY and NaY) and Mordenite (HMOR and NaMOR) zeolites. The systems were tested in single-step and in sequential processes. In single-step studies, HY zeolite was found to be the most efficient support when applied to low $\mathrm{Cr}$ concentrations (overall $\mathrm{Cr}$ removal of 93.4\%), whereas for the higher initial $\mathrm{Cr}$ concentration, the higher ion-exchange capacity of $\mathrm{NaY}$ zeolite was determinant to achieve the highest overall $\mathrm{Cr}$ removal of $77.6 \%$.

The evolution of $\mathrm{Cr}(\mathrm{VI})$ entrapment was strongly dependant on the zeolitic support used in the system. In sequential batch processes, $\mathrm{HY}$ zeolite was found to be the most efficient support with a $98.2 \%$ overall $\mathrm{Cr}$ removal. The reduction of $\mathrm{Cr}(\mathrm{VI})$ promoted by the biomass is more suited to the dynamics of the sequential process. NaY zeolite behaved similarly to HMOR and NaMOR zeolites, as these systems removed between 87.3 and $93.4 \%$ of the initial $\mathrm{Cr}$.
\end{abstract}

(C) 2010 Elsevier B.V. All rights reserved.

\section{Introduction}

Heavy metal contamination of the environment is a direct consequence of human activity. The discharge of these elements into water sources poses a health risk, since heavy metals are not biodegradable and accumulate in organisms [1]. Lead, iron, copper and chromium are common metals that accumulate in living organisms [2]. Moreover, the presence of these metals has a negative effect on the performance of biological waste treatment processes [3].

Chromium $(\mathrm{Cr})$ is a common pollutant from industries such as tanning, platting and textile dying [4]. This element is commonly found in the hexavalent or trivalent oxidation states, which are the most stable ones [5]. $\mathrm{Cr}(\mathrm{VI})$ is highly soluble in a wide $\mathrm{pH}$ range and can diffuse through cellular membranes reacting with intracellular biomolecules such as DNA, producing its carcinogenic effects $[5,6]$. The reduced mobility of $\mathrm{Cr}(\mathrm{III})$ and tendency to precipitate at neutral $\mathrm{pH}$ make this oxidation state less toxic to living cells.

\footnotetext{
* Corresponding author. Tel.: +351253604 400; fax: +351253678986.

** Corresponding author.

E-mail addresses: ineves@quimica.uminho.pt (I.C. Neves), ttavares@deb.uminho.pt (T. Tavares).
}

Several technologies for the treatment of metal contaminated wastewater are currently available. Adsorption and ion-exchange are some of the most popular [7]. However, $\mathrm{Cr}(\mathrm{VI})$ is commonly found in the form of the chromate and dichromate anions. The electrostatic repulsions from these ions render most treatment processes inefficient or expensive to operate [8]. The most commonly applied technologies for $\mathrm{Cr}$ treatment are "removal-disposal" processes, like chemical precipitation or concentration [4]. The current research efforts are directed towards "recovery-reuse" technologies, in order to address both environmental and economical concerns.

A technology for the treatment of $\mathrm{Cr}$-containing solutions consisting of a biosorbent supported on zeolite has been proposed recently [8-10]. This technology combines the known capacity of bacteria to remove metals from solution with the ion-exchange ability of zeolites. The Si/Al framework ratio of the zeolite determines its maximum ion-exchange capacity; however the real capacity may be lower if a portion of the charge compensation cations are inaccessible to the exchanging ion. The aperture dimensions control exchanging ion entry into zeolite cavities, and may be a limiting factor during the ion-exchange process [11].

Zeolites are crystalline aluminosilicate compounds whose crystalline structure is formed by channels and cavities of strictly regular dimensions called micropores, that can be found naturally or produced synthetically and are commonly considered an 
inexpensive class of materials suitable for the removal of heavy metals $[1,7,12]$. However, charge repulsions between the net negative charge of the zeolite framework and the charge on chromate and dichromate anions make direct removal of $\mathrm{Cr}(\mathrm{VI})$ species inefficient for these supports.

The usage of microbial biomass for the removal of heavy metals is well reported in the literature [13], being known as an environmentally clean process. The combination of biomass with the zeolite results in a system that is able to remove $\mathrm{Cr}(\mathrm{VI})$ via a two-step process: bioreduction of $\mathrm{Cr}(\mathrm{VI})$ to $\mathrm{Cr}(\mathrm{III})$ followed by ionexchange of the formed $\mathrm{Cr}(\mathrm{III})$, performed by the zeolitic structure. After loading the zeolite with the exchanged $\mathrm{Cr}$, the biomass is removed by thermal treatment and the resulting inorganic support can be reused as a $\mathrm{Cr}$ catalyst for oxidation reactions in liquid or gas phase $[9,14,15]$. Reduction of $\mathrm{Cr}(\mathrm{VI})$ to $\mathrm{Cr}(\mathrm{III})$ performed by bacteria is commonly reported in the literature [5]. The complex composition of cell walls and extra-cellular biomolecules, such as extracelular polysaccharides [16], offer many electron donor groups that can assist the reduction of $\mathrm{Cr}(\mathrm{VI})$ to $\mathrm{Cr}(\mathrm{III})$ by a process called "adsorption-coupled-reduction" [17,18].

The biomass chosen for the $\mathrm{Cr}$ treatment system was the non-pathogenic Arthrobacter viscosus bacterium. Arthrobacter sp. bacteria are known to tolerate exposition to concentrated $\mathrm{Cr}(\mathrm{VI})$ [6]. The presence of this ion triggers the thickening of the external cell wall [19], which would also allow some additional retention of the metal by the bacterium. Moreover, $A$. viscosus is a good exopolysaccharide (EPS) producer [20], which endows this bacterium with ability for adhesion to a support and enhances metal retention capacity [21]. The role of the EPS is also important for the reduction of $\mathrm{Cr}(\mathrm{VI})$ to $\mathrm{Cr}(\mathrm{III})$, since polysaccharide chains contain several diol groups that have been found to contribute to the reduction of $\mathrm{Cr}(\mathrm{VI})$ [19,22].

This work presents a focus on the applicability of the A. viscosuszeolite system in metallic ions entrapment supplied by $\mathrm{Cr}(\mathrm{VI})$ containing solutions. The operation in different batch modes, single-step and sequential mode was also conducted.

Different zeolitic structures were compared to access the influence of the support: FAU-type (HY and NaY) and MOR-type (HMOR and NaMOR) zeolites. These zeolitic structures, so called large pore, are different. As it is well known, Y zeolite is a microporous aluminosilicate based on sodalite cages joined by $\mathrm{O}$ bridges between the hexagonal faces. Eight such sodalite cages are linked together, forming a large central cavity or supercage, with a diameter of $12.5 \AA$. The supercages share a 12 -membered ring with a diameter of $7.4 \AA$. In contrast with Y zeolite, mordenite zeolite does not present supercages; instead, it presents bidimensional channels with 12-membered ring apertures with a diameter of $7.0 \AA ̊ \times 6.5 \AA$ connected by short alternating 8 -ring channels $(\approx 3 \AA)$. The respective chemical formulas for sodium form of zeolites are $\mathrm{Na}_{58}\left[\mathrm{Al}_{58} \mathrm{Si}_{134} \mathrm{O}_{384}\right] \cdot 240 \mathrm{H}_{2} \mathrm{O}$ for FAU and $\mathrm{Na}_{8}\left[\mathrm{Al}_{8} \mathrm{Si}_{40} \mathrm{O}_{96}\right] \cdot 24 \mathrm{H}_{2} \mathrm{O}$ for MOR [23].

\section{Experimental}

\subsection{Materials and reagents}

A. viscosus was obtained from the Spanish Type Culture Collection of the University of Valencia. The zeolites HY (CBV400), NaY (CBV100), $\mathrm{NH}_{4} \mathrm{MOR}(\mathrm{CBV} 21 \mathrm{~A})$ and NaMOR(CBV10A) were obtained from Zeolyst International in powder form. All zeolites were calcinated for $8 \mathrm{~h}$ at $500{ }^{\circ} \mathrm{C}$ under dry air flow $(50 \mathrm{~mL} / \mathrm{min}$ ) prior to use. The zeolite $\mathrm{NH}_{4} \mathrm{MOR}$ was available in the ammonium form. After heating, the ammonium is transformed into $\mathrm{NH}_{3}$ and $\mathrm{H}^{+}$. $\mathrm{NH}_{3}$ desorbs and the presence of the protons increases the number of acid sites. The protonic form of MOR (HMOR) was obtained after this calcination. All aqueous $\mathrm{Cr}(\mathrm{VI})$ solutions were prepared by diluting
$\mathrm{K}_{2} \mathrm{Cr}_{2} \mathrm{O}_{7}$ (Panreac, p.a.) in distilled water, with $\mathrm{pH}$ set to 4.0 with the addition of $\mathrm{H}_{2} \mathrm{SO}_{4}(4.0 \mathrm{M})$.

\subsection{Biomass growth and concentration}

A. viscosus was grown for $24 \mathrm{~h}$ at $28^{\circ} \mathrm{C}$ in a culture medium with the following composition: $10.0 \mathrm{~g} / \mathrm{L}$ of glucose, $5.0 \mathrm{~g} / \mathrm{L}$ of peptone, $3.0 \mathrm{~g} / \mathrm{L}$ of malt extract and $3.0 \mathrm{~g} / \mathrm{L}$ of yeast extract. The $\mathrm{pH}$ of the culture medium was set to 7.0 prior to sterilization and inoculation. The biomass was centrifuged on a Sigma 4K15 centrifuge (RCF of 7950) and the supernatant was collected on a sterile bottle for later use. The biomass pellets were re-suspended on a smaller volume of the collected medium, being this volume calculated as to obtain a concentration up to $5.0 \mathrm{~g}_{\text {biomass }} / \mathrm{L}$ (effective biomass concentration ranged between 4.7 and $4.9 \mathrm{~g} / \mathrm{L}$, for all assays).

\subsection{Single-step batch assays}

The single-step batch assays were performed in $250 \mathrm{~mL}$ erlenmeyer flasks. Each flask received $1.0 \mathrm{~g}$ of zeolite, $17.0 \mathrm{~mL}$ of concentrated biomass suspension, calculated for a final concentration of $5.0 \mathrm{~g}_{\text {biomass }} / \mathrm{L}$ and $150 \mathrm{~mL}$ of $\mathrm{Cr}(\mathrm{VI})$ solution $\left(50.0 \mathrm{mg}_{\mathrm{Cr}} / \mathrm{L}\right.$ or $100.0 \mathrm{mg}_{\mathrm{Cr}} / \mathrm{L}$ ). The $\mathrm{pH}$ on every flask was set initially to 4.0 , with the addition of $\mathrm{H}_{2} \mathrm{SO}_{4}(4.0 \mathrm{M})$ when necessary, as previous optimization studies indicated this value to be the most adequate [24]. Each specific combination of zeolite and $\mathrm{Cr}(\mathrm{VI})$ concentration was tested in duplicate. The flasks were kept in an orbital incubator at $28^{\circ} \mathrm{C}$, with moderate stirring, for 27 days. The $\mathrm{pH}$ was constantly measured and kept at 4.0 with the addition of $\mathrm{H}_{2} \mathrm{SO}_{4}(4.0$ or $1.0 \mathrm{M})$, when necessary. Samples of the solution $(1.0 \mathrm{~mL})$ were withdrawn at established intervals and centrifuged, recovering the supernatant solution. At the end of the 27 days, the solid contents on each flask were recovered by centrifugation and the supernatant solution was rejected. After drying the solid at $60^{\circ} \mathrm{C}$ for 3 days, the samples were calcinated at $500^{\circ} \mathrm{C}$ for $8 \mathrm{~h}$, with dry air flow $(40 \mathrm{~mL} / \mathrm{min})$ to ensure decomposition of the organic matter for downstream processing of the solid matrices.

\subsection{Sequential batch reactor (SBR) assays}

The SBR assays were conducted with $100 \mathrm{mg}_{\mathrm{Cr}} / \mathrm{L}$ solutions. The initial stage was set identically to the single-step batch studies and a cycle time of 4 days was established. At the end of the first cycle, the flasks were removed from the incubator, each solution was centrifuged and the supernatant liquid was recovered. From each recovered solution, $150.0 \mathrm{~mL}$ were transferred to another flask with $1.0 \mathrm{~g}$ of zeolite and $17.0 \mathrm{~mL}$ of concentrated $A$. viscosus suspension ("reactor 2", identical to the one previously used). The flasks were kept at $28^{\circ} \mathrm{C}$ in an orbital incubator for another 4 days, with moderate stirring. After that time, the process was repeated to start the third and final cycle. The solid samples from collected from each reactor were recovered after the centrifugation step, extensively dried at $60^{\circ} \mathrm{C}$ for 3 days and calcinated at $500^{\circ} \mathrm{C}$ for $8 \mathrm{~h}$, within a dry air flow (40 mL/min).

\subsection{Analytical procedures}

The mass concentration of the concentrated biomass suspension was confirmed by the dry weight method. The concentration of $\mathrm{Cr}(\mathrm{VI})$ was determined by the 1,5-diphenylcarbazide method [25]. Total $\mathrm{Cr}$ was determined by oxidation of the samples with excess potassium permanganate [17] and analyzed by the 1,5diphenylcarbazide method. Chromium loading on zeolitic samples was evaluated according to the SMEWW 3120 method, using Inductive Coupled Plasma (ICP) performed in "Laboratório de Análises" of the Instituto Superior Técnico, Portugal. 
Table 1

Physicochemical properties of the zeolite samples.

\begin{tabular}{lllll}
\hline & NaY & HY & NaMOR & HMOR \\
\hline $\mathrm{Si} / \mathrm{Al}$ & $2.83^{\mathrm{a}}$ & $2.80^{\mathrm{a}}$ & $6.50^{\mathrm{b}}$ & $10.00^{\mathrm{b}}$ \\
$\mathrm{Na}(\%)^{\mathrm{c}}$ & 7.76 & 1.95 & 4.82 & 0.06 \\
$\mathrm{~S}_{\mathrm{BET}}\left(\mathrm{m}^{2} / \mathrm{g}\right)$ & $787^{\mathrm{d}}$ & $730^{\mathrm{b}}$ & $425^{\mathrm{b}}$ & $500^{\mathrm{b}}$ \\
& & & & \\
\hline
\end{tabular}

a Total Si/Al ratio and sodium amount determined from ICP-AES [26]

b Data from Zeolyst International.

c Number of sodium ions drawn from the unit cell formula of the zeolites [26].

d Determined by nitrogen adsorption [27].

\section{Results and discussion}

Different zeolitic structures were tested in this work: FAUtype (HY and NaY) and MOR-type zeolites (HMOR and NaMOR). These zeolites are microporous aluminosilicates which have internal structures with an open diameter of $7 \AA$ while the characteristic dimension of the $A$. viscosus bacterium ranges from 1 to $10 \mu \mathrm{m}$. Due to these limitations, the $A$. viscosus bacterium is supported on the outer surface of the zeolite support [14].

The zeolites differ in terms of chemical composition and $\mathrm{Si} / \mathrm{Al}$ ratio. Table 1 presents the physiochemical properties of the zeolites.

The Si/Al ratio, sodium amount and surface areas are very different in these zeolitic structures. The sodium amount in the zeolite structure plays an important role in the ion-exchange capacity.

Both forms of Y zeolites presented similar Si/Al ratios, different sodium amounts and exhibit large specific surfaces areas, typically higher than $700 \mathrm{~m}^{2} \mathrm{~g}^{-1}$, greatly depending on the structure and on the chemical composition of the many different zeolites. However, the $\mathrm{Si} / \mathrm{Al}$ ratios of MOR zeolites are higher than FAU zeolites, due to their chemical composition which reveal the lower sodium amount in their structure. The $\mathrm{Si} / \mathrm{Al}$ ratio of NaMOR is lower than HMOR, due to higher amount of aluminium atoms in this zeolite. The lowest value of sodium amount is observed for HMOR and the highest for $\mathrm{NaY}$, due to the presence of the larger amount of $\mathrm{Na}$ ions per unit cell (47.2) [26]. The higher ion-exchange capacity is evident in the case of FAU zeolites, due to the lower $\mathrm{Si} / \mathrm{Al}$ ratio and higher sodium amount per unit cell and present in their structure.

\section{1. $p H$ behaviour of the solutions under treatment}

The reactors containing the zeolitic support and the $A$. viscosus suspension were initially set to $\mathrm{pH} 4.0$ and constantly monitored thereafter. The biomass concentration of $5.0 \mathrm{~g} / \mathrm{L}$ and a $\mathrm{pH}$ of 4.0 were found to be the most adequate operating conditions for the treatment of $\mathrm{Cr}(\mathrm{VI})$ solutions up to $100 \mathrm{mg}_{\mathrm{Cr}} / \mathrm{L}$, based on previous studies [24]. A 27-day experimental time was set in order to follow the behaviour of the system on the long term.

The $\mathrm{pH}$ of the $\mathrm{Cr}(\mathrm{VI})$ solutions was initially set to 4.0 , but shifted upon addition of $\mathrm{NaY}$ or NaMOR zeolite to the reactors. The $\mathrm{pH}$ increase is due to the hydrolysis of these supports in contact with water [28], according to Eq. (1). The reactors using hydrogencontaining zeolites (HY and HMOR) behave differently, since the exchange of $\mathrm{H}^{+}$ions does not alter the $\mathrm{pH}$ of the solution.

$\mathrm{H}^{+}(\mathrm{aq})+\mathrm{Na}^{+}($Zeo $) \rightarrow \mathrm{Na}^{+}(\mathrm{aq})+\mathrm{H}^{+}$(Zeo)

Charge compensation by co-exchange of protons from aqueous solution leads to some residual acidity in the zeolite. This residual acidity has an effect on the catalytic behaviour of the samples in the oxidation reactions [9].

The systems using sodium-containing zeolites required a higher amount of sulphuric acid at the initial stages, to compensate for the initial $\mathrm{pH}$ shift. The $\mathrm{pH}$ increased slowly thereafter, only requiring minimal amounts of $\mathrm{H}_{2} \mathrm{SO}_{4}$ to maintain the $\mathrm{pH}$ at 4.0. The addition of HY or HMOR zeolite and concentrated biomass suspension to the
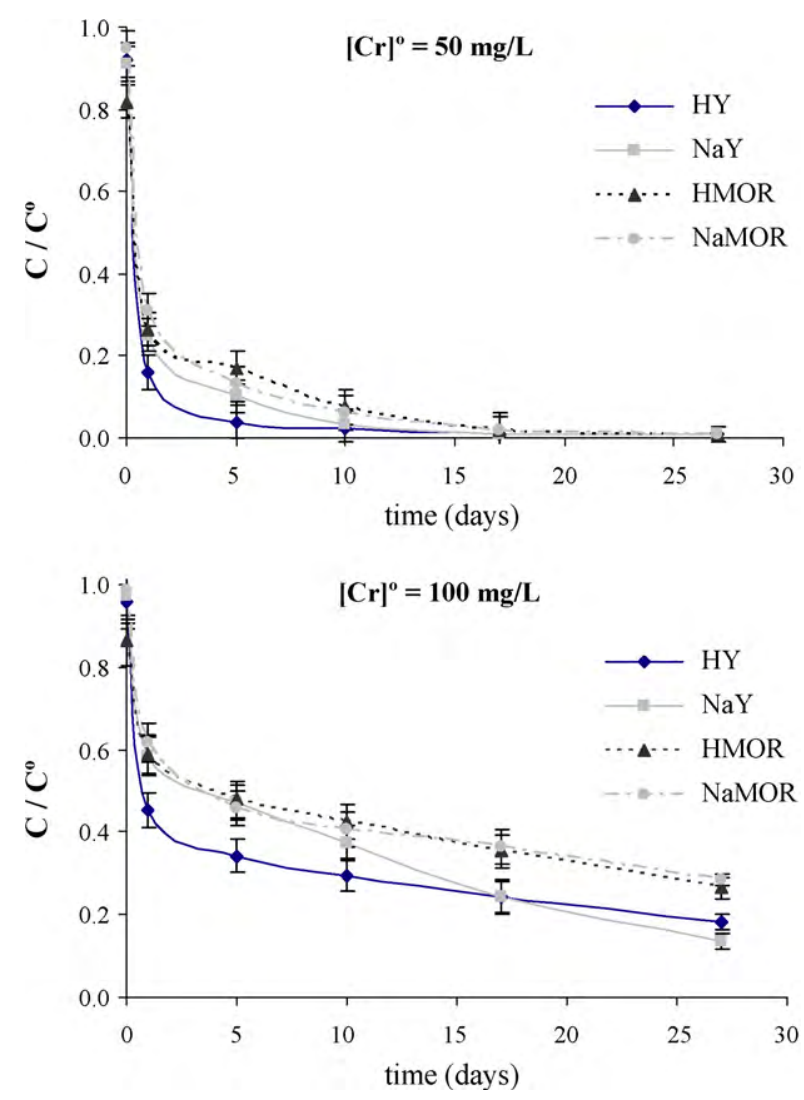

Fig. 1. Evolution of instant over initial $\mathrm{Cr}(\mathrm{VI})$ concentration $\left(C / C^{0}\right)$ vs. time, for initial $\mathrm{Cr}(\mathrm{VI})$ concentrations of 50 and $100 \mathrm{mg}_{\mathrm{Cr}} / \mathrm{L}$.

$\mathrm{Cr}(\mathrm{VI})$ solution results in a mixture with pH between 3.8 and 4.0. After $24 \mathrm{~h}$, the $\mathrm{pH}$ on the system increased slightly, only requiring minimal amounts of sulphuric acid to maintain the $\mathrm{pH}$ of the system at 4.0 .

A slight increase in $\mathrm{pH}$ was observed in all systems after an experimental time of $24 \mathrm{~h}$, which is due to the consumption of $\mathrm{H}^{+}$ ions during the reduction of $\mathrm{Cr}(\mathrm{VI})$ species.

\section{2. $\operatorname{Cr}(V I)$ removal by a single-step process}

The $\mathrm{Cr}(\mathrm{VI})$ removal capacity of a single-step process was evaluated for all zeolites and two different initial $\mathrm{Cr}(\mathrm{VI})$ concentrations.

The evolution of $\mathrm{Cr}(\mathrm{VI})$ concentration in liquid phase along the assays is presented in Fig. 1. For both initial $\mathrm{Cr}$ concentrations, all systems show typical biosorption kinetics, with a faster decrease of the concentration of $\mathrm{Cr}(\mathrm{VI})$ during the first $24 \mathrm{~h}$ followed by a second and slower reduction period [29].

All systems were able to completely remove $\mathrm{Cr}(\mathrm{VI})$ from solution for an initial concentration of $50 \mathrm{mg}_{\mathrm{Cr}} / \mathrm{L}$, which was achieved after 17 days. For the higher initial concentration, $\left(100 \mathrm{mg}_{\mathrm{Cr}} / \mathrm{L}\right)$, no system achieved complete removal of $\mathrm{Cr}(\mathrm{VI})$, at least for 27 days.

The systems using HY and HMOR present a more efficient initial $\mathrm{Cr}(\mathrm{VI})$ removal stage, compared to their sodium counterparts. This effect is more perceptible between the two Y zeolites than between MOR zeolites. The availability of $\mathrm{H}^{+}$ions in HY or HMOR containing systems prompted a faster $\mathrm{Cr}(\mathrm{VI})$ reduction by the biomass, which is known to be favoured in acidic medium [30]. The consumption of $\mathrm{H}^{+}$ions in the reduction process also explains the slow increase in $\mathrm{pH}$ observed after $24 \mathrm{~h}$.

For the most concentrated $\mathrm{Cr}(\mathrm{VI})$ solution, NaY based system shows a more efficient second removal stage than HY zeolite system (observed after $24 \mathrm{~h}$ ). The greater potential of $\mathrm{NaY}$ to exchange 

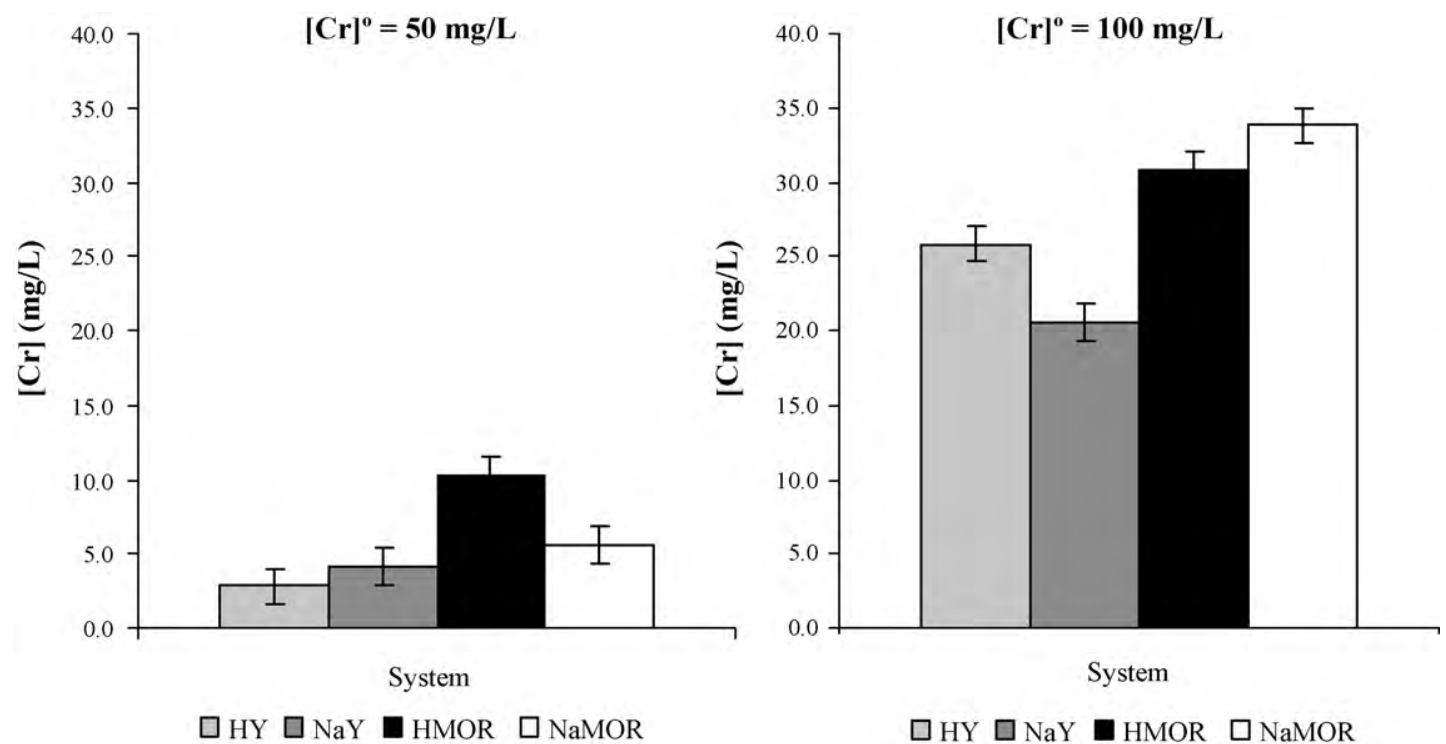

Fig. 2. Final total $\mathrm{Cr}$ concentration for the different systems, for initial $\mathrm{Cr}(\mathrm{VI})$ concentrations of $50 \mathrm{and} 100 \mathrm{mg}_{\mathrm{Cr}} / \mathrm{L}$.

$\mathrm{Na}^{+}$ions with the $\mathrm{Cr}(\mathrm{III})$ species (formed through biomass reducing activity) can explain this distinguished second removal stage, as the $\mathrm{Cr}$ (III) species are more easily removed from solution by the zeolite. This effect is less pronounced in MOR zeolites, whose behaviour is quite comparable for either 50 or $100 \mathrm{mg}_{\mathrm{Cr}} / \mathrm{L}$ initial concentrations. The smaller ion-exchange capacity of MOR zeolites, compared to FAU [31], is responsible for the similar behaviour of HMOR and NaMOR based systems (Table 1 ).

After the conclusion of the assay, the recovered solutions were analysed for total chromium contents. The results are presented in Fig. 2.

Although the removal of $\mathrm{Cr}(\mathrm{VI})$ was complete for an initial concentration of $50 \mathrm{mg}_{\mathrm{Cr}} / \mathrm{L}$, the analysis for total chromium revealed the presence of this metal in solution. This is due to the presence of reduced $\mathrm{Cr}$ species that are unable to be exchanged by the supporting zeolite. This is most likely caused by the coordination of some of the formed $\mathrm{Cr}$ (III) ions with biomolecules or cellular metabolites, as it is reported in studies of bioreduction of $\mathrm{Cr}(\mathrm{VI})$ [5,31]. Moreover, the fragmentation of EPS chains that still retain the ion may occur. The dimension of these compounds renders diffusion through the zeolite pores and channels impossible and the chromium species remain in solution.

The final $\mathrm{Cr}$ concentrations in liquid solution are comparatively lower in FAU zeolites systems, for either initial $\mathrm{Cr}$ dosages. This difference is again explained by the greater ion-exchange capacity of these supports. While there is little difference on the residual $\mathrm{Cr}$ concentration between $\mathrm{HY}$ and $\mathrm{NaY}$ systems for an initial concentration of $50 \mathrm{mg}_{\mathrm{Cr}} / \mathrm{L}$, for a higher initial concentration, $\mathrm{NaY}$ based system was able to remove a higher amount of $\mathrm{Cr}$. This is in accordance to the data previously obtained for hexavalent chromium. MOR zeolites perform differently, as HMOR based system was less efficient for a lower initial concentration, whereas for the $100 \mathrm{mg}_{\mathrm{Cr}} / \mathrm{L}$ solution, the amount of residual chromium is slightly lower for HMOR than for NaMOR system.

Table 2 resumes the performance of the different systems in terms of $\mathrm{Cr}$ uptake and removal. $\mathrm{Cr}$ uptake is defined as mass of accumulated metal per mass of zeolite and $\mathrm{Cr}$ removal is the mass of retained $\mathrm{Cr}$ over the initial $\mathrm{Cr}$ mass in the reactor.

\section{3. $\mathrm{Cr}(\mathrm{VI})$ removal by a sequential batch reactor (SBR) process}

The metallic ion retention ability of a SBR process was evaluated for all zeolites, from a solution with initial concentration of $100.0 \mathrm{mg}_{\mathrm{Cr}} / \mathrm{L}$. The process consisted in passing sequentially the $\mathrm{Cr}$ solution through three fresh biomass-zeolite reactors, with an established residence time of 4 days in each one. This experimental time was set based on the results obtained from the single-batch studies, as to allow the initial $\mathrm{Cr}(\mathrm{VI})$ reduction step to take place. Fig. 3 presents the evolution of $\mathrm{Cr}(\mathrm{VI})$ concentration in the liquid phase in these systems $\left(C / C^{0}\right.$ is defined as instant $\mathrm{Cr}(\mathrm{VI})$ concentration over initial concentration).

For FAU zeolite systems, the evolution of $\mathrm{Cr}(\mathrm{VI})$ concentration presents the same behaviour previously seen in the single-batch process, with a fast initial $\mathrm{Cr}(\mathrm{VI})$ removal followed by a gradual decrease in concentration until the end of the first cycle. The system containing $\mathrm{HY}$ zeolite is able to remove $\mathrm{Cr}(\mathrm{VI})$ more efficiently, which is in accordance with the results of the single-step process. For cycle two, the same biosorption kinetics dictates the evolution of $\mathrm{Cr}(\mathrm{VI})$ concentration, with HY based system outperforming once again its NaY counterpart. For the FAU zeolite systems, complete

Table 2

$\mathrm{Cr}$ removal and uptake for every system and all initial concentrations tested

\begin{tabular}{|c|c|c|c|c|}
\hline Initial $\mathrm{Cr}$ concentration $(\mathrm{mgCr} / \mathrm{L})$ & Zeolite & Initial $\mathrm{Cr}$ mass in the reactor $(\mathrm{mg})$ & $\mathrm{Cr}$ uptake by the system $(\mathrm{mg}) / \mathrm{g}_{\text {zeolite }}$ & Cr removal (\%) \\
\hline \multirow[t]{4}{*}{50} & HY & 7.71 & 7.2 & 93.4 \\
\hline & $\mathrm{NaY}$ & & 7.0 & 90.8 \\
\hline & HMOR & & 6.0 & 77.8 \\
\hline & NaMOR & & 6.8 & 88.2 \\
\hline \multirow[t]{4}{*}{100} & HY & 15.08 & 10.8 & 71.6 \\
\hline & $\mathrm{NaY}$ & & 11.7 & 77.6 \\
\hline & HMOR & & 9.9 & 65.6 \\
\hline & NaMOR & & 9.5 & 63.0 \\
\hline
\end{tabular}



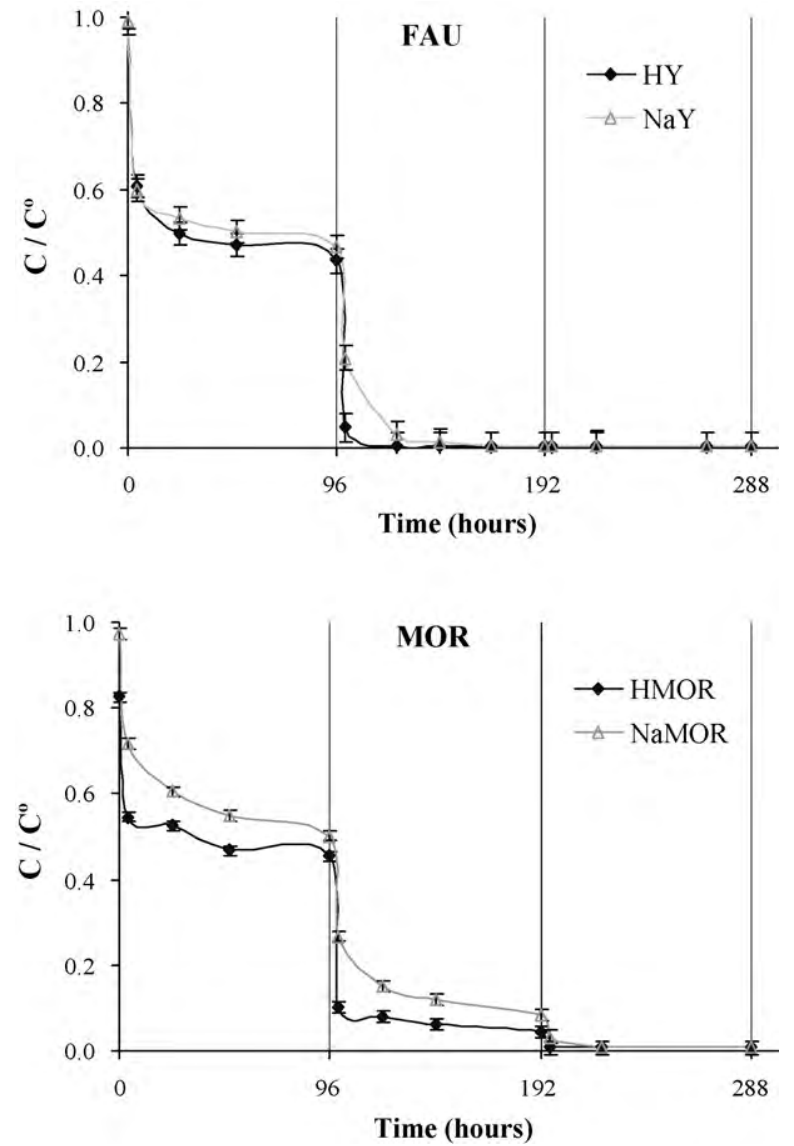

Fig. 3. Evolution of instant concentration of $\mathrm{Cr}(\mathrm{VI})$ over initial concentration $\left(C / C^{0}\right)$ within the different systems. The vertical lines indicate the change in reactor.

$\mathrm{Cr}(\mathrm{VI})$ removal occurs in the second cycle, after 24 and $48 \mathrm{~h}$ for HY and NaY systems, respectively. The third reactor cycle is redundant in terms of $\mathrm{Cr}(\mathrm{VI})$ evolution; however, it has some contribution for the decrease in total chromium concentration (Fig. 4).

HMOR based system is more efficient for the removal of $\mathrm{Cr}(\mathrm{VI})$ than NaMOR equivalent. However, both systems are less efficient than FAU containing counterparts, as the complete removal of $\mathrm{Cr}(\mathrm{VI})$ was only achieved at the third cycle. The smaller $\mathrm{Cr}(\mathrm{VI})$ removal efficiency of MOR zeolite systems is in accordance with the results obtained in the single-step assays.

At the end of each cycle, solutions were analysed for total chromium and the data are presented in Fig. 4. The removal and

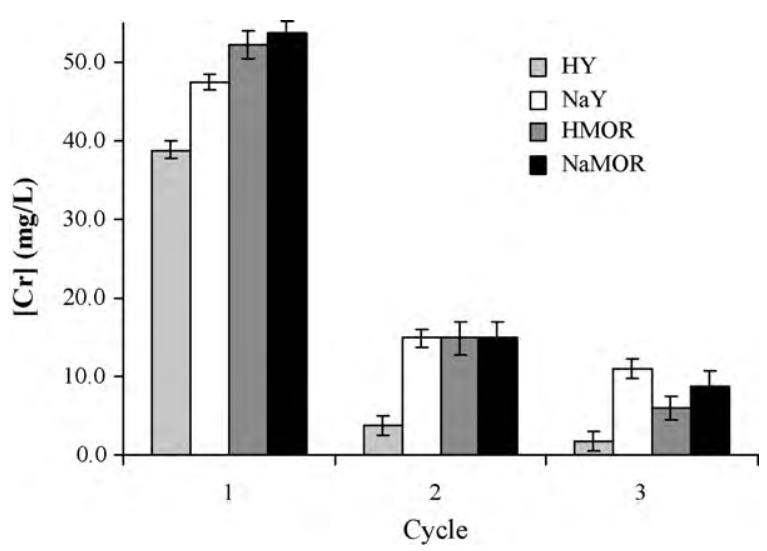

Fig. 4. Total $\mathrm{Cr}$ concentration at the end of each cycle for the different systems used.
Table 3

$\mathrm{Cr}$ removal and uptake for every system tested at the different cycles, for the sequential batch reactor assays.

\begin{tabular}{lllll}
\hline Zeolite & Overall Cr removal (\%) & \multicolumn{3}{l}{ Cr Uptake by the system (mg)/gzeolite } \\
\cline { 3 - 5 } & & Cycle 1 & Cycle 2 & Cycle 3 \\
\hline HY & 98.2 & 8.3 & 5.2 & 0.3 \\
NaY & 87.3 & 6.7 & 4.6 & 0.4 \\
HMOR & 93.4 & 6.5 & 5.3 & 1.3 \\
NaMOR & 90.5 & 6.2 & 5.5 & 0.8 \\
\hline
\end{tabular}

uptake values obtained by the different systems are presented in Table 3.

Although the removal of $\mathrm{Cr}(\mathrm{VI})$ was complete in all systems, the presence of chromium in solution was detected. The same fact was observed in the single-batch assays, which was attributed to the fraction of $\mathrm{Cr}(\mathrm{III})$ ions that coordinate with biomolecules produced by the bacteria [32] and to the fact that the resulting compounds are not likely to diffuse through the zeolite pores, as the pore opening of $7 \AA$ of either FAU or MOR type zeolites is considerably smaller than the size of most biological molecules.

In terms of overall capacity for $\mathrm{Cr}$ removal, HY system proved to be the most efficient, whereas the systems based on NaY, HMOR and NaMOR zeolites present comparable results. The faster initial reduction of $\mathrm{Cr}(\mathrm{VI})$ concentration promoted by HY zeolite is best suited to the established residence time of the SBR process. While NaY zeolite proved to be the most efficient support on the longer term experiments (single-batch), benefiting from the higher ionexchange capacity, this property is not helpful on the shorter SBR cycle time. MOR zeolites proved to be similar in behaviour, as the higher Si/Al ratio minimizes the difference in chemical composition (smaller $\mathrm{H}^{+}$or $\mathrm{Na}^{+}$availability). Despite needing an additional cycle to achieve complete $\mathrm{Cr}(\mathrm{VI})$ removal, the final $\mathrm{Cr}$ concentration is comparable to the one achieved with NaY.

The best zeolitic systems for $\mathrm{Cr}$ removal in both single-step and SBR processes, NaY and HY were submitted to thermal treatment, in order to remove the biomass and obtain $\mathrm{Cr}$-zeolite for application in further catalytic studies $[9,15]$. Table 4 presents the $\mathrm{Cr}$ loading on selected FAU zeolites, collected from the single-step assays (initial concentration of $100 \mathrm{mg}_{\mathrm{Cr}} / \mathrm{L}$ ) and from the SBR assays.

The results from bulk elemental analysis also provide interesting evidence on the dynamics of the removal of $\mathrm{Cr}(\mathrm{VI})$ and retention by HY or NaY zeolite-biomass systems. The samples of HY zeolite show similar Cr loading (0.50-0.60\% of metal) for the single step and for the first cycle of SBR, with identical initial conditions. This means that the retention of metal by this zeolite is most likely performed within 4 days. The retention of $\mathrm{Cr}$ which occurs beyond that point is performed by the biomass.

On the other hand, the comparison between the single-step and SBR samples of NaY zeolite proves that the retention of $\mathrm{Cr}$ (III) by the zeolite occurs differently to HY. The metal loading on the single-

Table 4

$\mathrm{Cr}$ loading of selected samples for the single-batch and sequential batch assays.

\begin{tabular}{|c|c|c|c|}
\hline Sample & & Cr loading (w/w\%) & \\
\hline \multicolumn{4}{|c|}{ Single-batch studies } \\
\hline HY & & 0.54 & \\
\hline $\mathrm{NaY}$ & & 0.75 & \\
\hline SBR studies & Cycle & & \\
\hline \multirow[t]{3}{*}{ HY } & 1 & & 0.59 \\
\hline & 2 & & 0.45 \\
\hline & 3 & & 0.04 \\
\hline \multirow[t]{3}{*}{$\mathrm{NaY}$} & 1 & & 0.46 \\
\hline & 2 & & 0.39 \\
\hline & 3 & & 0.05 \\
\hline
\end{tabular}


step sample presented the highest value at $0.75 \%$. Comparatively, the sample collected after the first cycle in SBR assays has a smaller loading, $0.46 \%$. This confirms that exchange of $\mathrm{Na}^{+}$ions with the reduced $\mathrm{Cr}$ species is responsible for the higher efficiency of $\mathrm{NaY}$ on the single-step assays. Furthermore, this fact also highlights the limitation of $\mathrm{NaY}$ system at the initial stages of the biotreatment process, which is responsible for the lower efficiency of this support in SBR process.

\section{Conclusion}

The results presented in this work show that different zeolitebiomass systems are able to perform the removal of $\mathrm{Cr}(\mathrm{VI})$ from solutions up to $100.0 \mathrm{mg}_{\mathrm{Cr}} / \mathrm{L}$. Different batch processes can be used, and the chemical composition of the zeolitic support promotes different system responses, in terms of removal of $\mathrm{Cr}(\mathrm{VI})$, bioreduction of $\mathrm{Cr}(\mathrm{VI})$ performed by $A$. viscosus and metal retention. Due to the higher ion-exchange capacity of NaY zeolite, this support is the most efficient for long-term $\mathrm{Cr}(\mathrm{VI})$ entrapment in single-step process, achieving $77.6 \% \mathrm{Cr}$ removal, compared to $71.6 \%$ for HY and $63-66 \%$ for MOR zeolites. For the SBR process, HY zeolite demonstrated to be the most attractive support, mainly due to the more efficient initial $\mathrm{Cr}$ removal ability of the system being more suited to the dynamics of the SBR process. Overall $\mathrm{Cr}$ removal was $98.2 \%$ with this support, whereas the other supports attained removal figures between 87 and 93\%. MOR zeolites show a better behaviour comparatively to $\mathrm{NaY}$ in SBR process, despite their lower ion-exchange capacity and $\mathrm{Cr}(\mathrm{VI})$ concentration reduction efficiency. However, for single-batch process, these facts limited MOR performance when compared to FAU counterparts.

In terms of metal retention, $\mathrm{NaY}$ zeolite was able to retain more Cr from single-step studies ( $0.75 \%$ vs. $0.54 \%$ for HY). In SBR process, HY achieved a slightly higher $\mathrm{Cr}$ loading compared to NaY in every cycle, being $0.59 \%$, the highest $\mathrm{Cr}$ loading obtained, at the end of the first cycle of HY-biomass system.

\section{Acknowledgments}

Hugo Figueiredo and Bruna Silva are thankful to the FCT Fundação para a Ciência e Tecnologia (FCT-Portugal), for the concession of their PhD grants. Cristina Quintelas is thankful to the same institution for the concession of a Pos-Doc grant. This work was supported by FCT under program POCTI-SFA-3-686.

\section{References}

[1] S.E. Bailey, T.J. Olin, R.M. Bricka, D.D. Adrian, A review of potentially low-cost sorbents for heavy metals, Water Res. 33 (1999) 2469-2479.

[2] E. Erdem, N. Karapinar, R. Donat, The removal of heavy metal cations by natural zeolites, J. Colloid Interface Sci. 280 (2004) 309-314.

[3] S. Compte, G. Guibaud, M. Baudu, Biosorption properties of extracellular polymeric substances (EPS) resulting from activated sludge according to their type: soluble or bound, Process Biochem. 41 (2006) 815-823.

[4] A. Agrawal, V. Kumar, B.D. Pandey, Remediation options of the treatment of electroplating and leather tanning effluent containing chromium-a review, Miner. Process Extr. Met. Rev. 27 (2006) 99-130.

[5] G.J. Puzon, R.K. Tokala, H. Zhang, D. Yonge, B.M. Peyton, L. Xun, Mobility and recalcitrance of organo-chromium(III) complexes, Chemosphere 70 (2008) 2054-2059.
[6] T.L. Kalabegishvili, N.Y. Tsibakhashvili, H.Y.N. Holman, Electron spin resonance study of chromium(V) formation and decomposition by basalt-inhabiting bacteria, Environ. Sci. Technol. 37 (2003) 4678-4684.

[7] O. Hernandez-Ramirez, S.M. Holmes, Novel and modified materials for wastewater treatment applications, J. Mater. Chem. 18 (2008) 2751-2761.

[8] B. Silva, H. Figueiredo, C. Quintelas, I.C. Neves, T. Tavares, Zeolites as supports for the biorecovery of hexavalent and trivalent chromium, Microsp. Mesosp. Mater. 116 (2008) 555-560.

[9] H. Figueiredo, I.C. Neves, C. Quintelas, T. Tavares, M. Taralunga, J. Mijoin, P. Magnoux, Oxidation catalysts prepared from biosorbents supported on zeolites, Appl. Catal. B Environ. 66 (2006) 274-280.

[10] C. Quintelas, Z. Rocha, B. Silva, B. Fonseca, H. Figueiredo, T. Tavares, Biosorptive performance of an Escherichia coli biofilm supported on zeolite NaY for the removal of $\mathrm{Cr}(\mathrm{VI}), \mathrm{Cd}(\mathrm{II}), \mathrm{Fe}(\mathrm{III})$ and $\mathrm{Ni}(\mathrm{II})$, Chem. Eng. J. 152 (2009) 110-115.

[11] C. Covarrubias, R. García, R. Arriagada, J. Yánez, M.T. Garland, Cr(III) exchange on zeolites obtained from kaolin and natural mordenite, Microsp. Mesosp. Mater. 88 (2006) 220-231.

[12] B. Sandhya, T.A. Kurniawan, Low-cost adsorbents for heavy metals uptake from contaminated water: a review, J. Hazard. Mater. B97 (2003) 219-243.

[13] M. Gavrilescu, Removal of heavy metals from the environment by biosorption, Eng. Life Sci. 4 (2004) 219-232.

[14] H. Figueiredo, B. Silva, M.M.M. Raposo, A.M. Fonseca, I.C. Neves, C. Quintelas, T. Tavares, Immobilization of Fe(III) complexes of pyridazine derivatives prepared from biosorbents supported on zeolites, Microsp. Mesosp. Mater. 109 (2008) $163-171$.

[15] H. Figueiredo, B. Silva, C. Quintelas, M.M.M. Raposo, P. Parpot, A.M. Fonseca, A.E. Lewandowska, M.A. Bañares, I.C.I. Neves, T. Tavares, Immobilization of chromium complexes in zeolite Y obtained from biosorbents: synthesis, characterization and catalytic behaviour, Appl. Catal. B Environ. 94 (2010) 1-7.

[16] F. Veglió, F. Beolchini, A. Gasbarro, Biosorption of toxic metals: an equilibrium study using free cells of Arthrobacter sp, Process. Biochem. 32 (1997) 99-105.

[17] D. Park, S.R. Lim, Y.S. Yun, J.M. Park, Reliable evidences that the removal mechanism of hexavalent chromium by natural biomaterials is adsorption-coupled reduction, Chemosphere 70 (2007) 298-305.

[18] D. Park, Y.S. Yun, J.Y. Kim, J.M. Park, Use of fermentation waste for detoxifying $\mathrm{Cr}(\mathrm{VI})$ in aqueous solution, Chem. Eng. J. 136 (2008) 173-179.

[19] Z. Lin, Y. Zhu, T.L. Kalabegishvili, N.Y. Tsibakhashvili, H.Y.N. Holman, Effect of chromate action on morphology of basalt-inhabiting bacteria, Mater. Sci. Eng. C26 (2006) 610-612.

[20] E. López, I. Ramos, M.A. Sanromán, Extracellular polysaccharides production by Arthrobacter viscosus, J. Food Eng. 60 (2003) 463-467.

[21] S. Lameiras, C. Quintelas, T. Tavares, Biosorption of $\mathrm{Cr}$ (VI) using a bacteria biofilm supported on granular activated carbon and on zeolite, Bioresour. Technol. 99 (2008) 801-806.

[22] N.Y. Tsibakhashvili, L.M. Mosulishvili, T.L. Kalabegishvili, E.I. Kirkesali, M.V Frontasyeva, E.V. Pomyakushina, S.S. Pavlov, H.Y.N. Holman, J. Radioanal. Nucl. Chem. 259 (2004) 527-531.

[23] C. Baerlocher, W.M. Meier, D.H. Olson, Atlas of Zeolite Framework Types, fifth ed, Elsevier Science, Amsterdam, 2001.

[24] B. Silva, H. Figueiredo, I.C. Neves, T. Tavares, The role of $\mathrm{pH}$ on $\mathrm{Cr}(\mathrm{VI})$ reduction and removal by Arthrobacter viscosus, Proceedings of the World Academy of Science, Eng. Technol. 43 (2008) 59-62.

[25] D. Eaton, L.S. Clesceri, A.E. Greenberg Standard Methods for the Examination of Water and Wastewater, American Public Health Association (APHA), Washington, 1995.

[26] I.C. Neves, G. Botelho, A.V. Machado, P. Rebelo, The effect of acidity behaviour of Y zeolites on the catalytic degradation of polyethylene, Euro. Polym. J. 42 (2006) 1541-1547.

[27] H. Figueiredo, B. Silva, C. Quintelas, M.F.R. Pereira, I.C. Neves, T. Tavares, Biosorption of hexavalent chromium based on modified $\mathrm{Y}$ zeolites obtained by alkali-treatment, Environ. Eng. Manage. J. 9 (2010) 305-311.

[28] H.S. Sherry, Ion exchange, in: S.M. Auerbach, K.A. Carrado, P.K. Dutta (Eds.), Handbook of Zeolite Science and Technology, Marcel Dekker, New York, 2003.

[29] C. Quintelas, T. Tavares, Removal of chromium(VI) and cadmium(II) from aqueous solution by a bacterial biofilm supported on granular activated carbon, Biotech. Lett. 23 (2001) 1349-1353.

[30] X. Han, Y.S. Wong, M.H. Wong, N.F.Y. Tam, Biosorption and bioreduction of $\mathrm{Cr}(\mathrm{VI})$ by a microalgal isolate, Chlorella miniata, J. Hazard. Mater. 146 (2007) $65-72$.

[31] V.J. Inglezakis, The concept of "capacity" in zeolite ion-exchange systems, J. Colloid Interface Sci. 281 (2005) 68-79.

[32] G.J. Puzon, A.G. Roberts, D.M. Kramer, L. Xun, Formation of soluble organochromium(III) complexes after chromate reduction in the presence of cellular organics, Environ. Sci. Technol. 39 (2005) 2811-2817. 